\title{
SEMI-QUANTITATIVE METHODOLOGY FOR DISASTER RISK ASSESSMENT: THE CASE STUDY OF PIPUS VILLAGE, AMAZONAS DEPARTMENT, PERU
}

\author{
JHON E. CHAHUA JANAMPA ${ }^{1 *} \&$ JHESSICA M. GUERRERO PINEDO ${ }^{2}$ \\ ${ }^{1}$ National Center for Estimation, Prevention and Reduction of Disaster Risk, Ministry of Defense, Peru \\ ${ }^{2}$ Provincial Municipality of Chachapoyas, Regional Government of Amazonas, Peru
}

\begin{abstract}
The objective of this case study was to know the risk levels of Pipus village in Amazonas-Peru in order to have a technical document for the local government to access financial funds to implement actions for risk control and reduction associated with mass movements and floods. To achieve this objective a semi-quantitative methodology was applied based on the hierarchical analysis process. It allows an easy and fast way to quantify the qualitative variables (conditioning factors, triggering factors, fragility, resilience, etc.). For this, a geological, geomorphological and geodynamic mapping of the study area was carried out and the vulnerability index card filling for all the exposed elements as well, which were processed in a geographic information system. This methodology allowed characterizing the hazard, analyzing the vulnerability and calculating the risk of the elements exposed in Pipus village. Thirty seven homes were identified at very high risk of debris flow hazard; a landslide hazard in road; and river flood hazard in a bridge, sanitary system and communal premise, adding a total of six million PEN between damages and losses.

Keywords: semi-quantitative methodology, risk levels, landslide hazard, debris flow hazard, river flood hazard.
\end{abstract}

\section{INTRODUCTION}

The Peruvian territory is exposed to various natural events, due to the interaction between the physical conditions that a specific geographic area presents and the factors that trigger it. These events become natural hazards when they cause significant impacts on the population and their livelihoods.

In northern Peru, events due to mass movements and floods are frequent due mainly to rainfall, in which one of the affected places is the department of Amazonas, in which Pipus village is located. These events are recurrent in this populated center from December to March, in which two emergency reports due to landslides were registered [1], [2] this year.

Because of Pipus village does not have infrastructure, measures or actions to reduce the effects of these hazards, it is necessary to determine the risk levels to which the population and their livelihoods are exposed, in order to have a technical document that allows the local government to support the priority of taking risk control measures by accessing financial funds for the execution of these measures.

\section{METHODOLOGY}

To characterize hazards, analyze vulnerability and calculate risk, the methodology proposed by the National Center for Estimation, Prevention and Reduction of Disaster Risk (Cenepred, by its acronym in Spanish), which is the leading entity in disaster risk assessments, was used. This semi-quantitative methodology [3] is based on the hierarchical analysis process using

*ORCID: https://orcid.org/0000-0002-9922-0032 
the Saaty matrices [4] for the weighting between quantitative and qualitative variables, facilitating the stratification of hazard, vulnerability and risk levels, which are related to the following equation:

$$
\left.R_{i e}\right|_{t}=\left.f\left(P_{i}, V_{e}\right)\right|_{t}
$$

where $\mathrm{R}=$ risk; $P_{i}=$ hazard with intensity greater than or equal to $i$ during an exposure period $t$; and $V_{e}=$ vulnerability of an exposed element $e$.

To characterize the hazard, a multicriteria analysis is carried out identifying the factors to which the territory is conditioned, the factor that triggers the hazard and the hazard evaluation parameter (Fig. 1). Each of these factors is assigned a weighted weight, relating them to each other with the hierarchical analysis process.

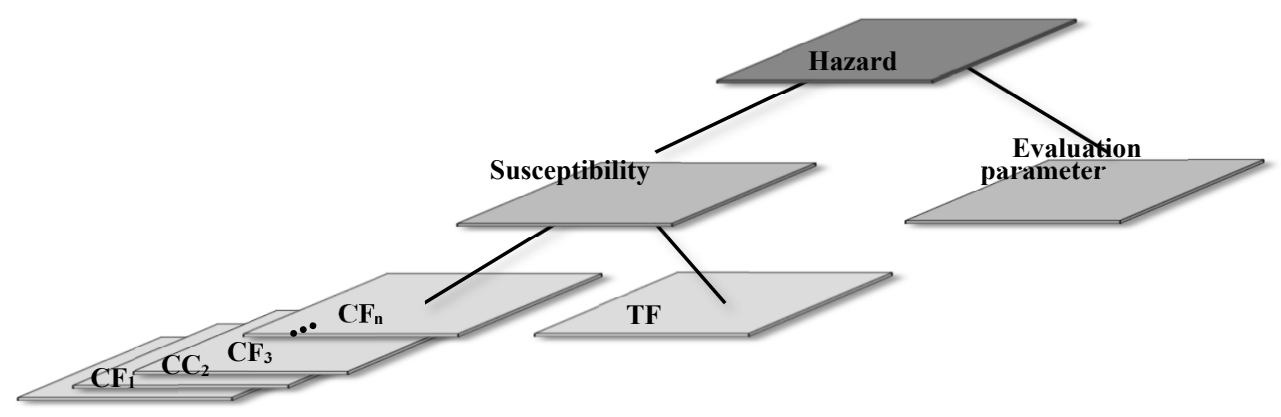

Figure 1: Hierarchical diagram for calculating the hazard. Note: $\mathrm{CF}_{1}, \mathrm{CF}_{2}, \mathrm{CF}_{3}, \ldots, \mathrm{CF}_{\mathrm{n}}=$ conditioning factors of the territory; $\mathrm{TF}=$ trigger factor.

The vulnerability analysis is obtained by relating its three factors: exposure, fragility and resilience, for each dimension considered in its analysis (social, economic and environmental). These dimensions will depend on the type of exposed element evaluated and a specific analysis must be carried out for each one of them. These dimensions and factors are related to each other with the hierarchical analysis process (Fig. 2).

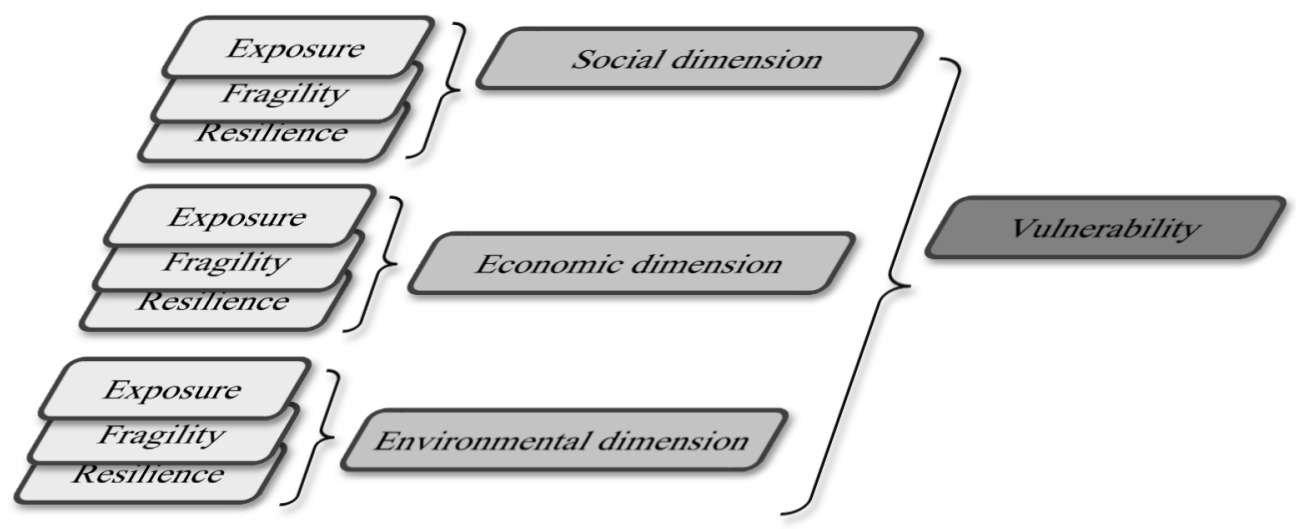

Figure 2: Hierarchical diagram for calculating vulnerability. 
With the calculations carried out, the hazard and vulnerability levels are stratified into four levels: Very high, high, medium and low. Each level presents a numerical range which is obtained during the calculation of the variables considered in the study through the hierarchical analysis process.

Finally, each hazard range is multiplied with vulnerability range to obtain risk ranges which are represented in its four levels. This methodology allows to quickly and easily calculate the risk levels to which the population and their livelihoods are exposed, focused on a scale of $1: 25,000$.

\section{CASE STUDY}

The study area (Fig. 3) comprises the Pipus village located in the San Francisco de Daguas district, Chachapoyas province and Amazonas department, at the coordinates UTM Zone 18 S: $197721 \mathrm{E}$ and $9311125 \mathrm{~N}$, at an altitude of 1990 masl.
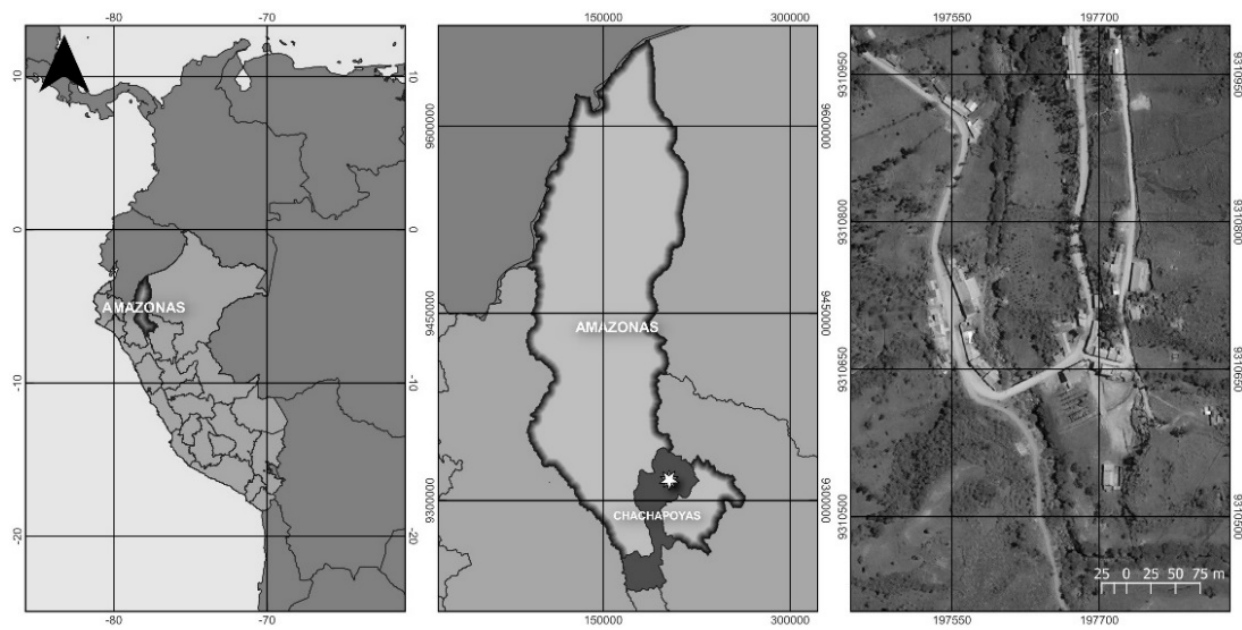

Figure 3: General location of Pipus village.

A field trip was carried out together with the technical team of the Geophysical Institute of Peru (IGP, by its acronym in Spanish) and the Chachapoyas provincial municipality in which a study of the geological, geomorphological and geodynamic characterization of the study area was carried out [5] which were inputs for the characterization of the hazard. Three main hazards were identified: fluvial flood, landslides and debris flow. Likewise, the historical record of the Chachapoyas meteorological station [6] was obtained for a period of 16 years (1996-2010) which were classified in thresholds with percentiles (99p-95p-90p$75 \mathrm{p}$ ) according to the methodology of the National Service of Meteorology and Hydrology of Peru (Senamhi, by its acronym in Spanish) [7]. For each type of hazard identified, its conditioning factors, triggering factor and its evaluation parameters (Table 1) obtained and previously treated were analyzed.

Table 1 shows the descriptors of each parameter and factor analyzed in a spatial manner for the three types of hazard identified in the study area, which will be used to obtain the hazard levels ranges. For the debris flow hazard, two ravines were identified: the Chilchos and Malcamal ravine, which were analyzed separately; however, they present the same factors and parameters for their calculation. 
Table 1: Factors and parameters analyzed for each type of hazard identified.

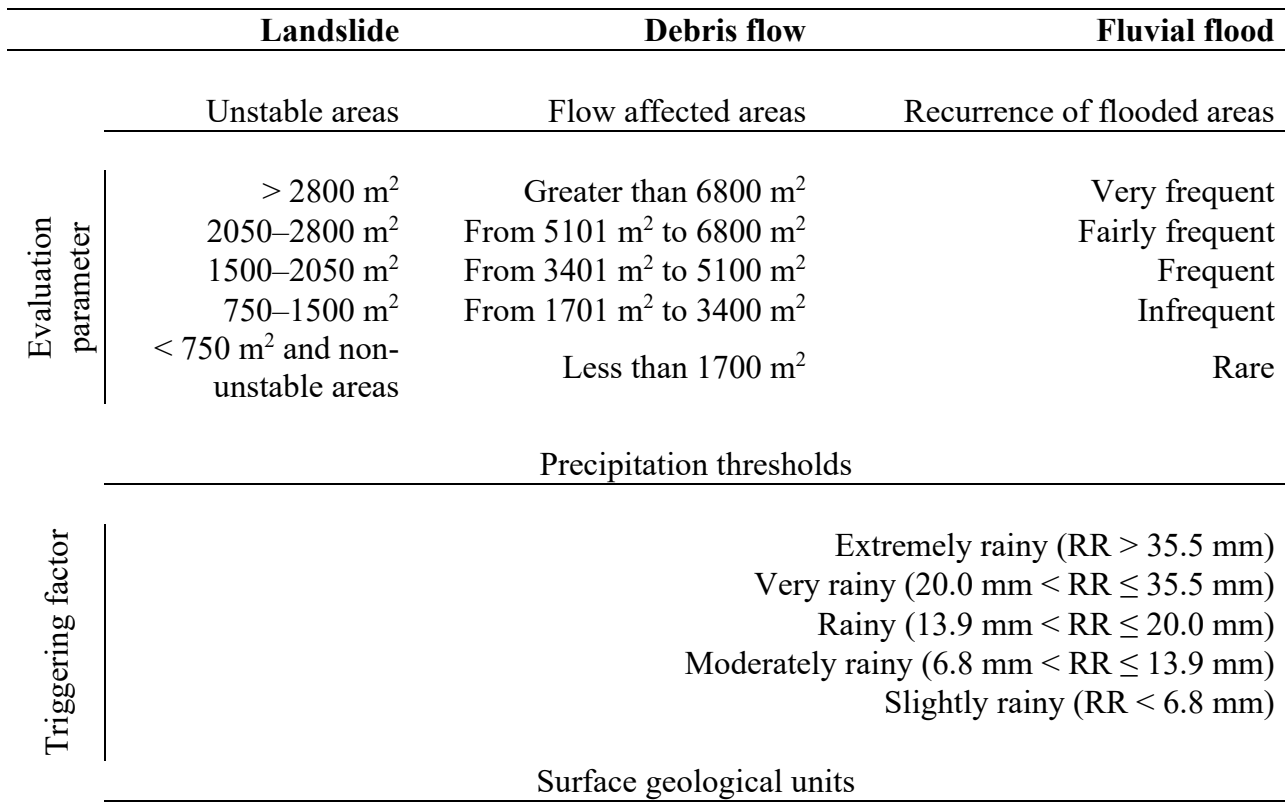

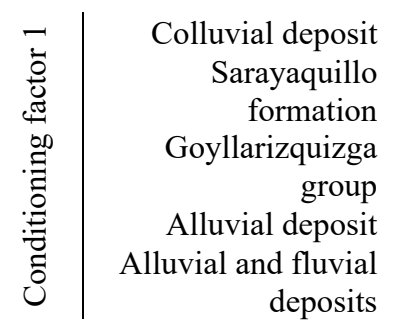

Alluvial deposit 2

River reservoir

Alluvial deposit

Alluvial deposit 1

Colluvial deposit

Alluvial deposit 1

Goyllarizquizga Group and

Sarayaquillo Formation

Alluvial deposit 2 and alluvial deposit

Colluvial deposit

Goyllarizquizga group and

Sarayaquillo formation

Geomorphological units

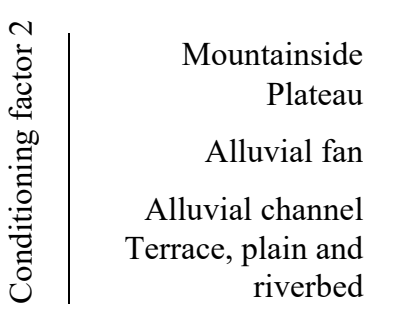

Alluvial channel

Alluvial fan

Alluvial terrace

Floodplain and riverbed

Plateau and mountainside
River bed

Flood plain

Alluvial terrace and alluvial channel

Alluvial fan

Plateau and mountainside

Slope of the terrain

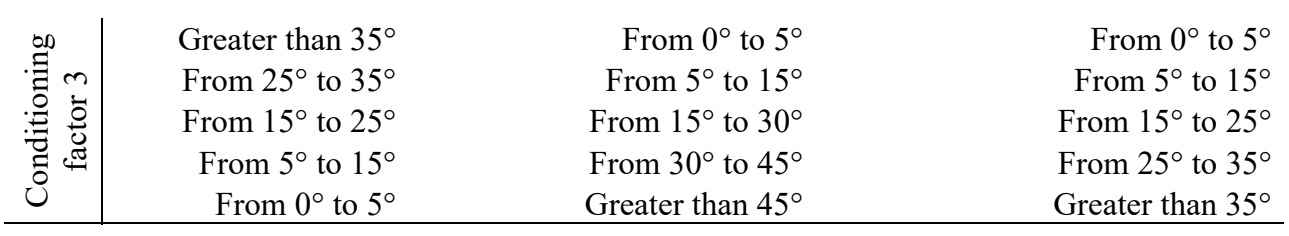


Table 2: Variables of the vulnerability factors for each element exposed to the hazard.

\begin{tabular}{|c|c|c|c|}
\hline $\mathrm{ti}$ & Exposure & Fragility & Resilience \\
\hline \multirow{4}{*}{$\begin{array}{c}\text { Houses } \\
\text { (debris flow) }\end{array}$} & \multicolumn{3}{|c|}{ Social dimension } \\
\hline & $\begin{array}{r}\text { Number of people per } \\
\text { house }\end{array}$ & Age group & $\begin{array}{r}\text { Educational level achieved } \\
\text { Type of insurance } \\
\text { Training on DRM issues }\end{array}$ \\
\hline & \multicolumn{3}{|c|}{ Economic dimension } \\
\hline & Close to hazard & $\begin{array}{r}\text { Predominant wall material } \\
\text { State of conservation } \\
\text { Antiquity }\end{array}$ & $\begin{array}{r}\text { Average family income } \\
\text { Labor regime }\end{array}$ \\
\hline \multicolumn{4}{|c|}{ Economic dimension } \\
\hline $\begin{array}{c}\text { Road } \\
\text { (landslide) }\end{array}$ & Close to hazard & State of conservation & $\begin{array}{r}\text { Compliance with construction } \\
\text { processes in accordance with } \\
\text { current regulations }\end{array}$ \\
\hline \multirow{3}{*}{$\begin{array}{l}\text { Bridge } \\
\text { (f. flood) }\end{array}$} & \multicolumn{3}{|c|}{ Economic dimension } \\
\hline & Close to hazard & State of conservation & $\begin{array}{r}\text { Compliance with construction } \\
\text { processes in accordance with } \\
\text { current regulations }\end{array}$ \\
\hline & \multicolumn{3}{|c|}{ Economic dimension } \\
\hline $\begin{array}{l}\text { Slaughterhouse } \\
\text { (f. flood) }\end{array}$ & Close to hazard & State of conservation & $\begin{array}{r}\text { Compliance with construction } \\
\text { processes in accordance with } \\
\text { current regulations }\end{array}$ \\
\hline \multirow{3}{*}{$\begin{array}{l}\text { Parking } \\
\text { (f. flood) }\end{array}$} & \multicolumn{3}{|c|}{ Economic dimension } \\
\hline & Close to hazard & State of conservation & $\begin{array}{r}\text { Compliance with construction } \\
\text { processes in accordance with } \\
\text { current regulations }\end{array}$ \\
\hline & \multicolumn{3}{|c|}{ Economic dimension } \\
\hline \multirow{4}{*}{$\begin{array}{l}\text { Sewage system } \\
\text { (f. flood) }\end{array}$} & Close to hazard & State of conservation & $\begin{array}{r}\text { Compliance with construction } \\
\text { processes in accordance with } \\
\text { current regulations }\end{array}$ \\
\hline & \multicolumn{3}{|c|}{ Environmental dimension } \\
\hline & Close to water sources & $\begin{array}{r}\text { Exploitation of natural } \\
\text { resources on the banks of } \\
\text { the river }\end{array}$ & $\begin{array}{l}\text { Knowledge and compliance with } \\
\text { environmental regulations }\end{array}$ \\
\hline & Close to the landfill & & $\begin{array}{l}\text { Training of operators in } \\
\text { environmental conservation }\end{array}$ \\
\hline
\end{tabular}


Table 3: Values of the hazard, vulnerability and risk levels range.

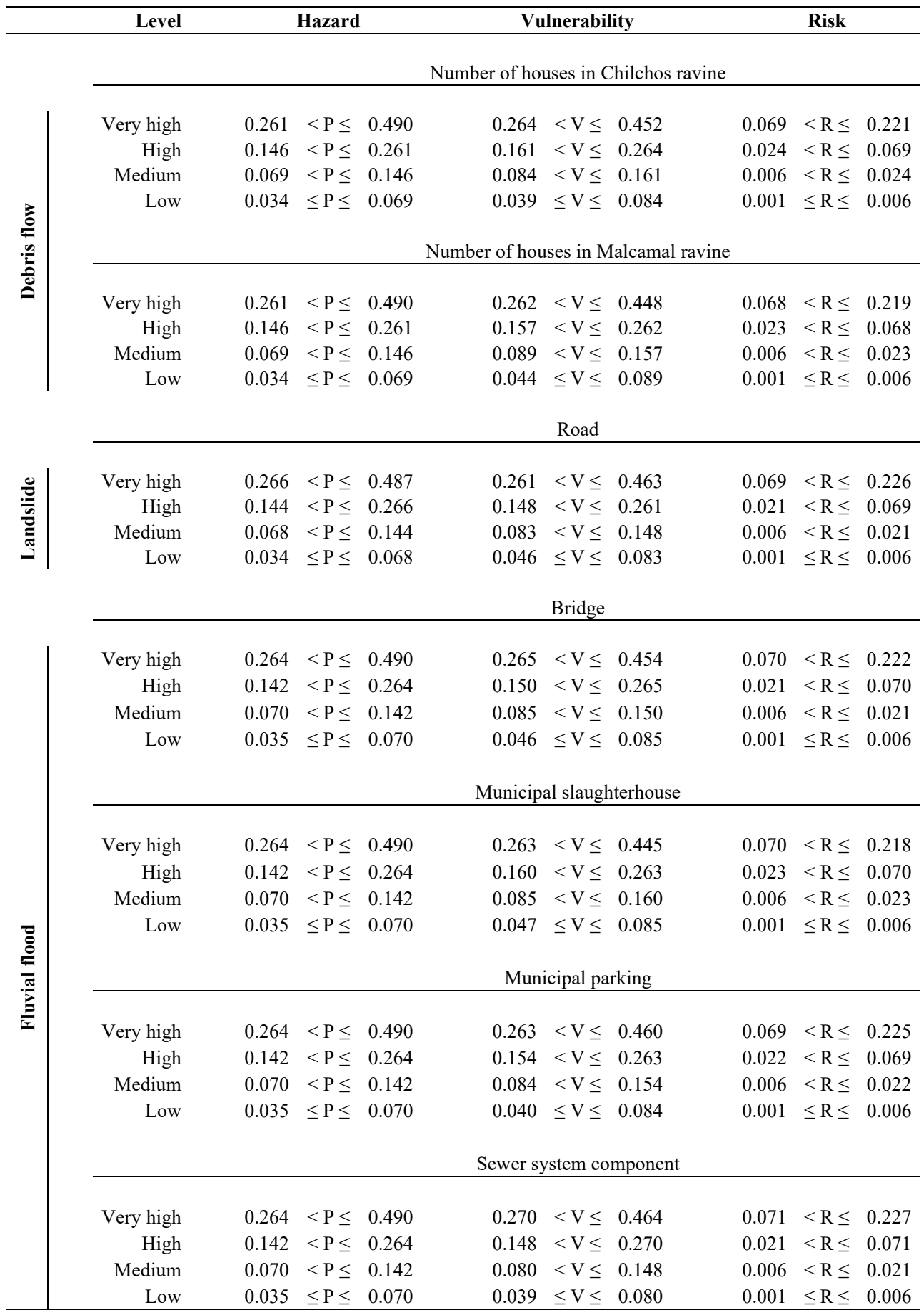


Table 4: Quantity of elements exposed to hazard, vulnerability and risk levels.

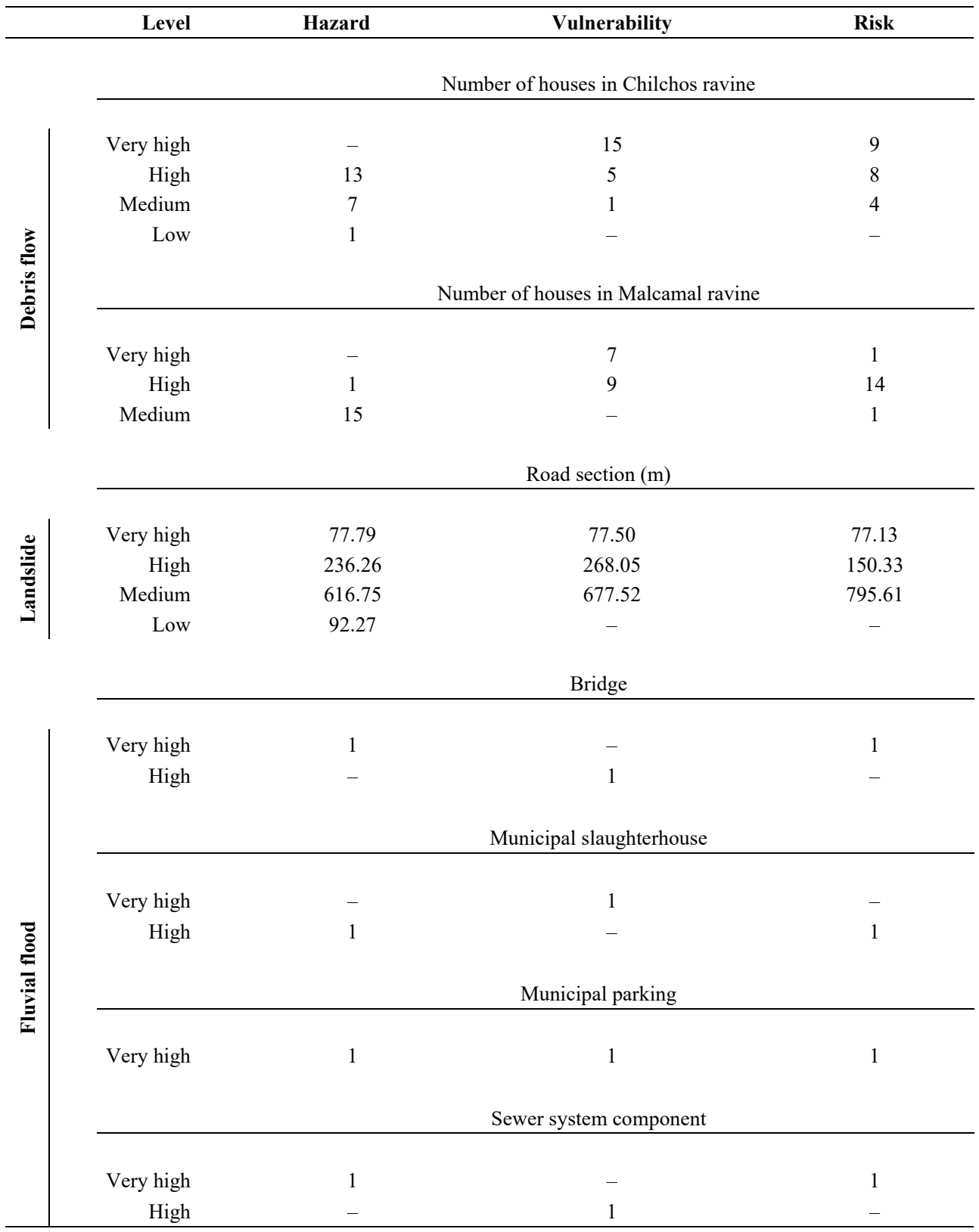

For the vulnerability analysis, files were generated with specific data on exposure, fragility and resilience for each type of element exposed to these hazards. Houses were identified as being exposed to debris flow hazard; the local road to landslide hazard; and the bridge, municipal parking, municipal slaughterhouse and the sewage system component to fluvial flood hazard (Table 2). 

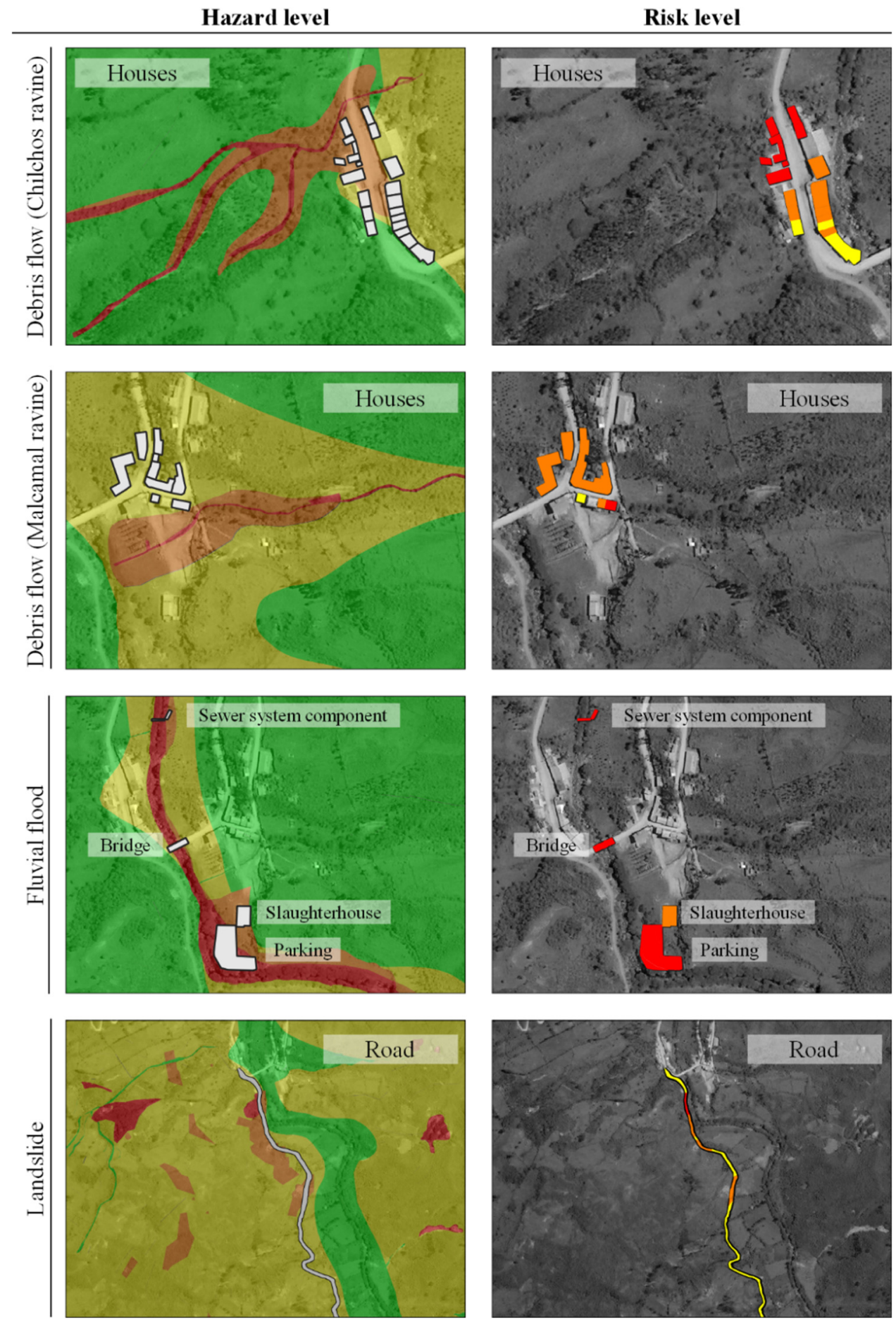

Figure 4: Hazard and risk maps according to the type of element exposed in Pipus village. 
Table 2 shows the variables used for each factor and dimension of vulnerability used to calculate the vulnerability levels range.

The variables presented in Tables 1 and 2 were worked with the hierarchical analysis process to obtain the weighted weights of each of the variables.

\section{DISCUSSION AND RESULTS}

The weighted weights were calculated with the hierarchical analysis process of the variables presented in Tables 1 and 2, in which the hazard, vulnerability and risk levels range were obtained for each type of danger and exposed element. (Table 3).

The ranges of values in Table 3 were used to classify the hazard, vulnerability and risk levels presented by the different elements exposed for each type of hazard, which are shown in Table 4.

In Table 4, it can be seen that the exposed elements are mostly with high and very high risk levels, in which only one house presents a medium risk level to debris flow hazard and a 795 meter stretch of The road presents a medium risk level to landslide hazard. Hazard and risk levels can be seen spatially in Fig. 4, according to type of hazard and type of exposed elements.

Likewise, a quantification was made of the probable effects that these three hazard may cause in Pipus village (Table 5), classified according to damage value, determined by the value of the physical assets destroyed; and losses, determined with the value of changes in the production flows of goods, services and the provision of additional services (emergency care, humanitarian aid, temporary tents, etc.).

Table 5: Probable effects of hazards in Pipus village according to type of hazard.

\begin{tabular}{lccc}
\hline \multicolumn{1}{c}{ Hazard } & Probable effects & & \\
\hline Debris flow in Malcamal ravine & $\mathrm{S} / 2,590,150.00$ & $\mathrm{~S} / 223,000.00$ & $\mathrm{~S} / 2,813,150.00$ \\
Debris flow in Chilchos ravine & $\mathrm{S} / 2,144,300.00$ & $\mathrm{~S} / 193,300.00$ & $\mathrm{~S} / 2,337,600.00$ \\
Landslide & $\mathrm{S} / 155,250.00$ & $\mathrm{~S} / 35,500.00$ & $\mathrm{~S} / 190,750.00$ \\
Fluvial flood & $\mathrm{S} / 680,000.00$ & $\mathrm{~S} / 320,000.00$ & $\mathrm{~S} / 1,000,000.00$ \\
\hline & $\mathrm{S} / 5,569,700.00$ & $\mathrm{~S} / 771,800.00$ & $\mathrm{~S} / 6,341,500.00$ \\
\hline
\end{tabular}

Note: The values are expressed in PEN national currency with the symbol $\mathrm{S} /$.

In Fig. 4, the location of the different elements exposed to the evaluated hazard is observed, in which it is appreciated that the risk levels oscillate between very high and medium, which indicates that immediate and priority activities must be developed for control and risk reduction.

Likewise, in Table 5, it is possible to observe the different probable effects that these hazards may cause, which amount to a total sum of S /. 6’341,500.00 between damages and losses in the Pipus village.

\section{CONCLUSIONS AND RECOMMENDATIONS}

The semi-quantitative methodology for the evaluation of the risk disasters caused by natural hazards allowed to quickly know the different hazard, vulnerability and risk levels to which the different types of exposed elements are found.

The risk due to the debris flow in the houses of the Chilchos ravine is dominated by the very high level, while in the Malcamal ravine the high level predominates, causing a total effect of $S / .5 ' 150,750.00$ which leads to an unacceptable risk, which can be reduced with 
the construction of flow diversion channels along the ravine and reforestation with pine trees in the upper part of the ravine to stabilize the slopes, in which the volumes of solids that contribute to the formation of debris flows are present.

On the road evaluated, the landslide risk that predominates is the medium level, causing a total effect of S /. 190,750.00, therefore, the construction of the channeling of surface and underground water is recommended to reduce the water table, retaining walls for protection on the road and reforestation with pine trees in the upper part of the slopes to stabilize the susceptible slope to landslides.

The fluvial flood risk would cause a total effect of S /. 1'000,000.00 in which the very high level predominates. To reduce this risk, the construction of riverine defenses with gabion and reinforced concrete walls is recommended on both banks of the Olia River, which will reduce the effects of erosion and contain the volume of water in times of flooding of the river.

The non-structural measures that are recommended for risk reduction and control is to propose processes to strengthen organizational capacities in Pipus village, train the population in compliance with technical construction standards, conduct awareness talks on management of the disaster risk and promote environmental practices for the preservation of ecosystems.

Finally, the results of the risk assessment reports will allow local authorities to technically support the risk levels present in the Pipus village in order to gain access to financing for risk reduction and control works through the different financial programs in Peru.

\section{ACKNOWLEDGEMENT}

The collaboration of the technical team of the Geophysical Institute of Peru for the elaboration of the geological, geomorphological and geodynamic characterization in Pipus village, the technical team of Chachapoyas Provincial Municipality for the preparation of the risk assessment reports and the National Center for Estimation, Prevention and Reduction of Disaster Risk for technical assistance in the preparation of reports.

\section{REFERENCES}

[1] Instituto Nacional de Defensa Civil, Centro de Operaciones de Emergencia Nacional, Deslizamiento en el distrito de San Francisco de Daguas - Amazonas, 2021. https://www.indeci.gob.pe/wp-content/uploads/2021/03/INFORME-DEEMERGENCIA-N\%C2\%BA-290-6MAR2021-DESLIZAMIENTO-EN-ELDISTRITO-DE-SAN-FRANCISCO-DE-DAGUAS-AMAZONAS-1.pdf.

[2] Instituto Nacional de Defensa Civil, Centro de Operaciones de Emergencia Nacional, Deslizamiento en el distrito de San Francisco de Daguas - Amazonas, 2021. https://www.indeci.gob.pe/wp-content/uploads/2021/03/REPORTE-PRELIMINARN\%C2\%BA-973-25MAR2021-DESLIZAMIENTO-EN-EL-DISTRITO-DE-SANFRANCISCO-DE-DAGUAS-AMAZONAS.pdf.

[3] Centro Nacional de Estimación, Prevención y Reducción del Riesgo de Desastres, Manual para la evaluación de Riesgos originados por fenómenos naturales, 2014. http://www.cenepred.gob.pe/web/wp-content/uploads/Guia_Manuales/ManualEvaluacion-de-Riesgos_v2.pdf.

[4] Saaty, T.L., Decision making with the analytic hierarchy process. Services Science, 1(1), p. 86, 2008. https://doi.org/10.1504/IJSSci.2008.01759.

[5] Instituto Geofísico del Perú, Caracterización geológica, geomorfológica y geodinámica del poblado de Pipus, distrito de San Francisco de Daguas, provincia de Chachapoyas y departamento de Amazonas, 2021. 
[6] Servicio Nacional de Meteorología e Hidrología del Perú, Datos hidrometeorológicos a nivel nacional, 2021. https://www.senamhi.gob.pe/?\&p=estaciones.

[7] Servicio Nacional de Meteorología e Hidrología del Perú, Estimación de umbrales de precipitaciones extremas para la emisión de avisos meteorológicos, 2014.

https://cdn.www.gob.pe/uploads/document/file/811068/01402SENA-6.pdf. 